\title{
Urgensity of Environmental Management System Implementation on Oil Palm Plantation Management Policies in North Sumatera
}

\author{
Ade Parlaungan Nasution ${ }^{1 *}$, Edwin Agung Wibowo ${ }^{2}$, Ramdani Ramdani ${ }^{2}$, \\ Tamama Rofiqah ${ }^{2}$
}

${ }^{1}$ Universitas Labuhan Batu, Labuhan Batu, Sumatera Utara, 21412, INDONESIA

${ }^{2}$ Universitas Riau Kepulauan, Batam, Kepulauan Riau, 29438, INDONESIA

*Corresponding Author

DOI: https://doi.org/10.30880/jstard.2021.03.01.001

Received 3 March 2021; Accepted 16 May 2021; Available online 15 June 2021

\begin{abstract}
The development of oil palm plantations and its expansion as well, ensured potentially give impact on the environment. A standardized environmental management system is required by companies to develop and implement environmental aspects. This research is classified as a qualitative research with a case study which emphasizes potential environmental impacts analysis of oil palm plantations and the urgency of environmental management systems in oil palm plantation management policies in North Sumatra. The research results showed that there were potential environmental impacts began pre-construction, construction and operational stages related to oil palm plantations development such as erosion, changes of sustainable and quantity of water, plant pests distribution, diseases and weeds, changes in soil fertility, potential social conflicts and the emergence of the spread of plant diseases endemic and disruption of water infiltration function in peat areas. In addition, it affected environmental factors including ecosystem condition, hydrology, landscape, and resident's attitude around the plantation. Alternative policies which be carried out related to environmental preservation and community welfare are (1) agro-industrial development policies that process oil and palm oil waste, (2) Moratorium (temporary suspension) of illegal logging, (3) Establish policy synergies and improve communication between government agencies and institutions, (4) reduce conflicts over land freehold by reforming above the law.
\end{abstract}

Keywords: Environmental management, environmental impact, oil palm, plantation

\section{Introduction}

Indonesia is known an agricultural country which means depending on the agricultural sector as livelihood source and main food source as well (Netty, 2014). One of agricultural sub-sectors which currently growing rapidly and has considerable potential is the plantation. Contribution of plantation sub-sector to GDP was in third rank in 2009 after the food crops and fisheries sub-sector and has always been increasing year by year (Netty, 2014).

Oil palm has been as one of the mainstay commodities in the plantation sub-sector which attracted serious interest of government, investors and farmers, especially since the 1990s. Currently, Indonesia has approximately 10 million hectares of planted oil palm plantation (Dewi, 2014). Beyond that, around 18 million hectares of forest have been cutting down for oil palm plantation expansion (BPS, 2019). Oil palm is also one of Indonesia's export commodities which is quite important as a foreign exchange earner after oil and gas. In 2019, Indonesia was the largest producer and exporter of palm oil in the world with a total production in 2019 reached 20.9 million tons of palm oil, followed by Malaysia with a total production of 17.62 million tons (BPS, 2019). 
The development of oil palm plantations in North Sumatra also shows a positive growth trend, in 2019, the total area of oil palm in North Sumatra has reached 1,290,977 ha with a total production of 3,996,465 and employed around 4.7 million employees. The attractiveness and conducive supports, such as climatic conditions and supported prerequisites of availability of large areas and always positive growth every year give effect to oil palm plantations growing rapidly in North Sumatra (Efidayanthi \& Sumanjaya, 2013). Since production scale of oil palm plantations is in large, so the plantation business requires a large area and requires location requirements related to climate, soil conditions, and suitable area and a clear cultivation status. The development of oil palm plantations and its expansion as well, ensured potentially give impact on the environment, especially on ecosystems, hydrology and landscapes (Kangihade, 2013). Additionally, it affected environmental factors including ecosystem condition, hydrology, landscape, and resident's attitude around the plantation.

Environmental assessment in its application needs to be carried out in a structured and integrated management system in companies, especially in plantation companies. A standardized environmental management system specifies the requirements for an environmental management system that enables a company to develop and implement environmental aspects which are important in carrying out company operations with due regard to legal and information requirements. Basically, the Environmental Management System is a framework that a company will run, so that it can be known the stages of work which company undertakes so that the environment is maintained (BSN, 2005). This requires the organization to consider all relevant environmental issues in its operating process (Haerani, Rahardjo \& Nurtjahjono, 2014). Environmental Management System is defined as part of a management system used to manage environmental aspects, compliance with obligations, and risks associated with threats and opportunities The important role of oil palm plantations in the national economy, especially for regional development in the Provinces of Sumatra, makes managing oil palm plantations very important issues need solution. The current management system and government policies are deemed not fully able to accommodate the interests and needs of all stakeholders, which are marked by a number of problems and even conflicts between actors. For this reason, it is necessary to improve a number of policies by involving interested parties and who are directly or indirectly affected by the policies made by the government through comprehensive studies.

\section{Methodology}

In this case the researcher uses a qualitative research method with a case study approach that provides a systematic and accurate description of the actual facts and the characteristics of a particular population. A case study according to Hediansyah (2010) is a qualitative research model in detail about a particular individual or social unit over a certain period of time. Qualitative research emphasizes analysis on deductive and inductive data collection and analysis of the dynamics of the relationship between observed phenomena using scientific logic (Sugiyono, 2017). Thus the research will contain the results of literature review and analysis of field observations as well as data quotations to provide an overview of the presentation of the report, the data obtained comes from interviews and observations. This study seeks to describe a symptom or situation systematically so that the research subject becomes clearer in accordance with the objectives of the study, namely to provide an overview of the potential environmental impacts of oil palm plantations and the urgency of environmental management systems in oil palm plantation management policies in North Sumatra.

\section{Results And Discussion}

\subsection{Development of Oil Palm Plantations in North Sumatra}

Palm oil is also one of Indonesia's export commodities which is quite important as a foreign exchange earner after oil and gas. In fact, starting in 2006 Indonesia was able to catch up Malaysia, which previously was in ranked first in the palm oil business, where so far Malaysia is Indonesia's competitor in producing palm oil which controls the share of the palm oil market (BPS, 2009). The development of oil palm plantations in North Sumatra also shows a positive growth trend. North Sumatra is one of the largest producing areas for the commodity of Palm Oil (Alaeis) where the growth in area for the last 4 (four) years has reached $1.49 \%$ per year. According to statistical data, the total area of oil palm in 2015 reached 1,206,166.76 hectares and increased in 2018 to 1,260,080.95 hectares. When viewed from the production of palm oil, especially in the form of Fresh Fruit Bunches, the growth in the last 4 (four) years has experienced a positive trend, reaching 3.37\% per year where the production of Fresh Fruit Bunches in 2015 reached $18,512,737.25$ tons, an increase in in 2018 to $20,393,407.72$ tons.

The largest oil palm plantations in North Sumatra are in the districts of Asahan, Labuhanbatu, North Labuhanbatu, South Labuhanbatu, Langkat and Simalungun. The area is in accordance with the requirements for good growth and development for oil palm plants, which is at an altitude below 400 meters above sea level with an optimal temperature of 25-27 degrees Celsius. In addition, Padang Lawas, North Padang Lawas, Serdang Bedagai, Mandailing Natal and Deli Serdang are potential districts for oil palm development (Juliawati, Mulyadi \& Mubarak, 2014).

In order to support sustainable palm oil management in North Sumatra, a forum for sustainable palm oil in the province of North Sumatra has been established (FOKSBI SUMUT). The North Sumatra FOKSBI is a multistakeholder dialogue forum for the Palm Oil sector coordinated by the Plantation Office of North Sumatra Province. 
Evidence of commitment to the development of sustainable oil palm plantations and the achievement of the SDGs is contained in the Decree of the Governor of North Sumatra No. 118.44 / 343 / KPTS / 2018 dated 7 November 2018 Implementation that has been carried out is the preparation of an action plan for the province of North Sumatra which contains strategic action actions for the next five years (2019-2024).

The high demand for processed palm oil products has caused the planted area of oil palm plantations to continue to increase. This was also followed by efforts to increase production per unit of land by the Plantation Office of North Sumatra Province through intensification programs / activities. In addition, the support of the People's Palm Oil Rejuvenation Program in North Sumatra is a significant effort in the context of increasing production through replanting activities of old plants that require replanting (Henry, 2002). Therefore, the oil palm plantation sector is still a promising sector for the future. However, climatic factors that affect palm oil productivity and the fluctuating selling value of Fresh Fruit Bunches are a challenge for stakeholders engaged in this sector (Prisman, 2017). It is hoped that the role of local governments and business actors in the palm oil sector can be further enhanced through effective coordination and cooperation so that the welfare of oil palm farmers can increase.

\subsection{Analysis of Potential Impacts of Oil Palm Plantation Development}

The oil palm plant (Elaeis guineensis, Jack) originates from Africa. In English this plant is known as oil palm. The oil palm plant has a shape resembling a coconut tree. In Indonesia, oil palm is a non-native crop. The oil palm tree itself in Indonesia has been known since before the Second World War. Oil palm is cultivated in the form of a large plantation business. There were many legacies of oil palm plantations in North Sumatra. Meanwhile, currently, oil palm plantations are being developed in Sumatra and Kalimantan. Oil palms like fertile soil and open spaces (Dina, Chozin $\&$ Fauzi, 2012). Flowers and fruit in the form of bunch, and have many branches, tiny fruit, ripe fruit turns to blackish red. The flesh is dense. The flesh and skin of the fruit contain a lot of oil. Oil palm trees can reach up to 24 meters in height. Oil palms reproduced by seed and can thrive in the tropics. This plant begins to bear fruit around the age of $5-6$ years, but some types of crosses can bear fruit after the age of 36 months or about 3 years. Oil palm can produce fruit up to 60 years of age. The fruit yield per tree per harvest can reach 50 - 60 kilograms.

Currently, Indonesia is the world's largest producer of palm oil. Almost all parts of the oil palm tree can be used as industrial raw materials. The main product of oil palm trees is oil palm fruit. From the oil palm fruit, oil can be obtained as raw material for the food and non-food industries (Dewi, 2014). Oil palm fruit also produces coir for the pulp industry, particle board, or is burned as energy that can be used to drive machines in the palm oil processing plant itself. Likewise, sludge or sludge from the residual processing material, which is obtained from the waste after palm oil is taken, can still be used as raw material for the fertilizer industry or used as animal feed. Palm oil can also be used as the main ingredient for biodiesel or as a biofuel as a substitute for diesel oil (Natasaputra, Prastowo \& Chadiri, 2015). The large demand in the future will have an impact on the expansion of land use for oil palm plantations on a large scale. To replace $2 \%$ of national diesel demand, 720,000 kilo liters of biodiesel will be needed. For this purpose, 200,000 hectares (ha) of plantation land will be required.

Oil palm plantations can be classified as an annual plant cultivation business. Since the production scale of oil palm plantations is very large, the plantation business requires a large area of land. Oil palm cultivation requires location requirements related to climate, soil conditions and suitable land (Henry, 2002). Oil palm plants also require several suitable environmental requirements, such as rainfall, dry months, soil $\mathrm{pH}$, altitude, slope, soil texture, and soil that does not contain much rock. The land freehold status for oil palm plantations must be clear. In some areas, land use for plantations is only permitted in areas that already have Cultivation Rights Title ( $\mathrm{HgU})$. The use of community land must be considered carefully, whether it has received a mutually agreed agreement (Morrow, 2002). Beyond land freehold status, things that need to be known in relation to land are flora and fauna, topography, water sources and management (drainage), as well as definite area and area boundaries. Forest areas that are allowed to be used as land for oil palm plantations are forest areas that have been converted. Usually in the form of a production forest area or forest for other uses (UPL) which is converted into a plantation area. The development of oil palm plantations in forestry cultivation areas for all sizes is required by environmental impact analysis (AMDAL). Protected forest areas or forests that are protected for the purposes of supporting ecosystem functions, and conservation forests or forests for the purpose of preserving and protecting flora and fauna are forbidden for plantation business. Oil palm can thrive on peat lands, but oil palm plantations in peat areas need to pay attention to the function of the peat ecosystem, among others by building good drainage (Netty, 2014). The development of oil palm plantations as well as for the expansion that occurs in Sumatra, Kalimantan, and various other areas in Indonesia ensured have the potential to have an impact on the environment, especially on ecosystems, hydrology and landscapes (Prisman, 2017). The following descriptions will discuss some of the potential environmental impacts from the pre-construction, construction and operational stages related to the development of oil palm plantations.

Environmental impacts are defined as changes in the conditions and functions of an environmental component due to the sustainability of an activity component. Of course, special attention needs to be paid to the impacts that cause meaningful change (Terry, George, Leslie \& Rue, 2011). Oil palm plantation development activities that can affect the magnitude and nature of the impact include land acquisition and clearing, the location and area of large oil palm plantations with uniform crops (monoculture), as well as the construction and operation of oil palm fruit processing 
factories (Prisman, 2017). In addition, it affected environmental factors including ecosystem condition, hydrology, landscape, and resident's attitude around the plantation

Generally, impacts caused by the cultivation of plantation crops are erosion, changes of sustainable and quantity of water caused by land clearing activities, the spread of pests, diseases and weeds during plantation operations, and changes in soil fertility due to the use of pesticides. In addition, there are often potential social conflicts and the emergence of the spread of endemic plant diseases (Juliawati, Mulyadi \& Mubarak, 2014). The environmental impact of an activity needs to be recognized early on. The decision whether or not an activity is feasible to be realized must take into account the various environmental impacts that may arise. If the potential negative impacts are too large and are considered to exceed the potential positive impacts, the activity should not be realized (Kangihade, 2013). The UKL-UPL document must contain every possible environmental impact of the planned oil palm plantation activities that will be carried out in a specific, complete, and clear manner. At least what aspects, how, why, when, and where should be able to be answered. The location of land used for plantations will experience changes in the use and function of the ecosystem.

In peat areas, land clearing can result in disruption of the function of water absorption in the area. The impact caused by land conversion is a change in land and space use patterns. If the land used is land close to forest areas, it is expected that other impacts such as illegal logging and timber utilization will occur. The construction of an access road to the location of plantation land is tantamount to opening up regional accessibility (Dina, Chozin \& Fauzi, 2012). Areas that have been closed will be easy for the public to reach. Regional accessibility can have a positive or negative impact. Negative impacts can occur, for example on the existence of special objects, such as forest areas being threatened by encroachment, illegal logging, and illegal hunting of protected flora and fauna. With regard to location, the description above shows that oil palm plantations have a potential negative impact on ecosystems and land and space use patterns (Dewi, 2014). In addition, there will also be positive impacts, remote areas will become accessed.

Characteristics of Potential Impacts the impact will continue as long as the land is used as a plantation. If the area has an important ecosystem function, for example a peat area which is a water source area or a water catchment area for a large area, the impact will be very large and extensive. Severe ecosystem damage will result in flooding, drought, peatland fires, and other major environmental disasters. Impacts can appear continuously during the rainy season or the dry season. The obstacles that arise during land acquisition are from the community who are not willing to release their land and from the unsuitable selling price. These obstacles can affect the level of community acceptance of oil palm plantation development plans (Arief, Nawa, Reba \& Joko, 2017). Land acquisition affairs often lead to disputes among residents. People who refuse to sell their land will have opposite positions for other people who want to sell their land. This of course can damage the harmony of the population (Natasaputra, Prastowo \& Chadirin, 2015). Disputes between residents can also occur due to unclear land ownership status. The same land is recognized by two or more parties land sale and purchase transactions will affect the level of community income. As a consequence, community rights and ownership of the land will be lost (Kangihade, 2013). If it happens that the land is part of agricultural land, plantations, or land used by indigenous people, the activities could have a direct impact on their former livelihood patterns.

The description above shows that the potential environmental impacts associated with acquiring land for oil palm plantations have potential negative impacts on: community acceptance, community harmony, community rights and ownership, and livelihood patterns. On the other hand, the potential positive impact will be felt on increasing community income due to receiving compensation costs from the initiator. Some of the potential impacts associated with land acquisition begin to emerge at the pre-construction stage or when the proponent will determine the location of the plantation. When land acquisition is carried out, the potential impact will peak. Potential negative impacts can spread to all areas that are planned to become oil palm plantations, especially on lands where owners or users feel disturbed by the land acquisition plan.

\subsection{Environmental Management System in Oil Palm Plantation Management Policy}

ISO (International Organization for Standardization) is an organization that issues ISO 14001 regarding international standards regarding Environmental Management Systems. ISO published the ISO 14001 Environmental Management System (ISO 14001 Environmental Management System) for the first time in 1996 in Geneva, Switzerland (Morrow, 2002). The goal is to achieve improved management and control of environmental impacts. ISO 14001 is applicable to all types, sizes and organizational cultures. The Environmental Management System assists an organization in identifying, managing, monitoring and controlling aspects of its environment. This requires the organization to consider all environmental issues relevant to its operating processes (SNI, 2015).

Since the establishment of ISO 14001 as an international standard, various units of company organizations in Indonesia have voluntarily implemented the ISO 14001 Environmental Management System, which has become an indicator of increasing industrial awareness of environmental management (EKOLABEL in Netty, 2014). The benefits of implementing the ISO 14001 Environmental Management System have been felt by each organization, including:

1. Better environmental performance with reduced waste and pollution to the environment.

2. Improve the image of the organization in society and consumers with the assurance that it has helped protect the environment. 
3. Increasing competitiveness in national and international markets.

4. Save costs and energy through reducing the use of hazardous materials so as to reduce costs and efforts to treat waste and by reducing the use of fossil energy to new and renewable energy.

The development of an agro-industry that processes palm oil and palm oil waste is a policy alternative that is a top priority for optimal management of oil palm plantations. Along with the increasing area of oil palm land each year in the province of North Sumatra, it is predicted that it will produce more than 19 million tons of Fresh Fruit Bunches per year and 4.1 million tons of CPO per year (Prisman, 2017). This product has the potential to develop its downstream industry. This causes the production of Fresh Fruit Bunches to be unbalanced with existing palm oil mills. In order to balance the production of palm oil in the form of Fresh Fruit Bunches, additional palm oil mills are needed to accommodate the available Fresh Fruit Bunches in the surrounding area (Terry, George, Leslie \& Rue, 2011). However, with the increase in the number of Palm Oil Mill, there should be an agro-industrial development that processes palm oil waste which has an impact on environmental issues that are always being discussed at this time. So, with the development of an agro-industry that processes oil and palm oil waste because one of the causes of conflict in the development of oil palm plantations in North Sumatra is the many criticisms accused of the bad impact of oil palm on the environment and issues that result in weak competitiveness of Indonesian oil palm has had a negative impact on the continued development of a sustainable palm oil industry.

The development of plantations and the palm oil industry has even caused controversy in the international community. On the one hand, the development of oil palm and the oil palm industry provides welfare for the community and the country; on the other hand it has indispensable social and environmental impacts. For example: several European and American countries have boycotted palm oil products in protest of the negative social and environmental impacts it causes (Dina, Chozin \& Fauzi, 2012). The issue that has surfaced is that oil palm production which continues to increase in Indonesia (and Malaysia) has caused various negative impacts on the environment, including forest conversion, habitat loss, endanger species, as well as greenhouse effects and climate change. These issues have an impact on the instability of world CPO prices. Starting in 2011, the European Union has adopted the European Union Directive on the provision of greenhouse emissions. In this regulation, it is stated that the European Union cannot import CPO because this commodity is deemed not to meet the emission limitation provisions, as a result CPO cannot enter the European Union market (Disbun, 2019). To minimize the negative effects of oil palm plantation development by creating, environmentally friendly products, adhering to the triple bottom line concept, namely Profit, People and Planet, which means that every activity in this industry must always be guided and oriented to these three aspects. For this reason, several strategic steps have been launched, such as:

1. RSPO (Rountable Sustainable Palm Oil), which is an agency that issues certificates for companies that manage their plantations well and are environmentally friendly, and European countries will not accept palm oil exports without first having the RSPO certificate.

2.ISCC (International Sustainable Carbon Credit), which is also a certificate issued by European countries, where if the company already owns it, the price of palm oil per weight will be given a price premium (higher than the market price)

3. The government has issued a regulation stating that it is not permissible to manage oil palm plantations on peat soil.

4. Burning for plantation development is not justified (zero burning).

5. The existence of a plasma program, in which to better ensure that local communities enjoy the impact of the surrounding plantations, the company is obliged to build an oil palm plantation for community members 2 ha per family. plantations can be minimized.

Description of the main problems and issues which are happening in plantation locations related to the environment at this time, namely the low level of education so that the adoption and motivation of oil palm farmers to manage oil palm plantations as well is also low, unassertive government related to land clearing permittion for oil palm plantations occur conflicts over land between oil palm plantation companies and local communities resulting in issues of violence and human rights violations; unstoppable ecosystems damage; suboptimal empowerment of local communities causes social unrest; inadequate support for infrastructure and productivity technology.

\section{Conclusion}

The development of oil palm plantations in North Sumatra also shows a positive growth trend. The development of oil palm plantations and its expansion as well, ensured potentially give impact on the environment, especially on ecosystems, hydrology and landscapes. Additionally, it affected environmental factors including ecosystem condition, hydrology, landscape, and resident's attitude around the plantation. A standardized environmental management system specifies the requirements for an environmental management system that allows a company to develop and implement environmental aspects that are important in running company operations with due regard to legal and information requirements. In this case the researcher uses a qualitative research method with a case study which emphasizes analysis on deductive and inductive data collection as well as an overview analysis of the potential environmental 
impacts of oil palm plantations and the urgency of environmental management systems in oil palm plantation management policies in North Sumatra. The research results showed that there were potential environmental impacts began pre-construction, construction and operational stages related to the development of oil palm plantations. Generally, the impacts caused by the cultivation of plantation crops are in the form of erosion, sustainable and quantity of water changes caused by land clearing activities, the spread of pests, diseases and weeds during plantation operations, and changes in soil fertility due to the use of pesticides. In addition, there are often potential social conflicts and the emergence of the spread of endemic plant diseases. In peat areas, land clearing can result in disruption of the function of water absorption in the area. In addition, environmental factors that are affected include the condition of the ecosystem, hydrology, landscape, and the attitude of the people living in the area around the plantation. Based on the research results, it is concluded that a form of oil palm plantation management policy takes into account several aspects, namely ecological aspects, economic aspects, social aspects and institutional aspects. Activities that need to be prioritized in formulating a strategy for the management of oil palm plantations are environmental preservation, improving community welfare, then increasing the income of business actors. To realize this priority, there are 4 (four) most effective and most important policy alternatives that have an effect, namely ((1) agro-industrial development policies that process oil and palm oil waste, (2) Moratorium (temporary suspension) of illegal logging, (3) Establish policy synergies and improve communication between government agencies and institutions, (4) reduce conflicts over land freehold by reforming above the law.

\section{Acknowledgement}

We would like to thank the journal's editor and the anonymous reviewers for their positive feedback and suggestions for the improvement of this article

\section{References}

[1] Arief S, Nawa S, Reba AP, Joko PS. (2017). Energi terbarukan dan penguranagan emisi gas rumah kaca dari palmoil mill effluent. Jurnal Teknologi Lingkungan. (18)1: 88-95

[2] BPS. (2019). Badan pusat statistik Indonesia: Pertumbuha perkebunan sawit Indonesia dan daerah

[3] BSN. (2005). Badan standarisasi nasional: Sistem manajemen lingkungan-persyaratan dan panduan penggunaan. Standar Nasional Indonesia (SNI 19-14001-2005)

[4] Dewi, A. (2014). Analisis lingkungan sosial ekonomi pengelolaan perkebunan kelapa sawit berkelanjutan berdasarkan kriteria ISPO. Jurnal Sosio-Ekonomi dan Bisnis. 13(6): 21-35

[5] Dina H, Chozin, M. A., \& Fauzi A.M. (2012). Analysis on indonesian sustainable palm oil (ISPO): A qualitative assessment on the success factors for ISPO. Jurnal Manajemen \& Agribisnis. 9(1): 39-48

[6] Disbun. (2019). Profil komoditi tanaman tahunan perkebunan kelapa sawit di provinsi sumatera utara. http://disbun.sumutprov.go.id/?p=2799

[7] Efidayanthi, R., \& Sumanjaya, R. (2013). Peran perbankan terhadap petani kelapa sawit di kecamatan sosa kabupaten padang lawas sumatera utara. Jurnal Ekonomi dan Keuangan. (6) 1: 57-76

[8] Haerani, R. K., Rahardjo., G. E., \& Nurtjahjono. (2014). Pengaruh keselamatan dan kesehatan kerja terhadap kinerja karyawan. Jurnal Administrasi Bisnis. (15) 2: 1-7

[9] Henry L. (2002). Teknologi pengelolaan limbah industri kelapa sawit. Jurnal Teknologi Lingkungan. 3(3): 242250

[10] Herdiansyah. (2010). Metode penelitian kualitatif untuk ilmu-ilmu sosial. Salemba Humanika. Jakarta

[11] Juliawati, Mulyadi \& Mubarak. (2014). Manajemen lingkungan pada kegiatan industri sektor migas. Jurnal Ilmu Lingkungan. (8) 2: 158-170

[12] Kangihade (2013). Penerapan hukum tanggung jawab sosial perusahaan dalam kaitannya dengan pelestarian lingkungan dan masyarakat di indonesia. Jurnal Universitas Sam Ratulangi. (1) 3: 24-33

[13] Morrow (2002). Adopting corporate environmental management system: motivations and results of ISO 14001 and EMAS Certification. Journal (20)1:159-171. Elsevier Science Ltd. Great Britain

[14] Natasaputra, Prastowo, \& Chadirin. (2015). Efektivitas penerapan sistem manajemen lingkungan ISO 14001 di Pabrik Ban XYZ-Jawa Barat. Jurnal Manusia dan Lingkungan. (22) 3: 398-406

[15] Netty, K. (2014). Karakterisasi dan potensi pemanfaatan limbah sawit. Bandung: Itenas Library

[16] Prisman, S. (2017). Kajian aspek sosial dan lingkungan perkebunan kelapa sawit berdasarkan ISPO (Indonesian Sustainable Palm Oil) di PTPN VIII Tambaksari Subang, Jawa Barat. Sumedang (ID): Universitas Padjadjaran.

[17] SNI ISO 14001. (2015). Sistem manajemen lingkungan persyaratan dengan panduan penggunaan. Badan Standarisasi Nasional

[18] Sugiyono. (2017). Metode penelitian kuantitatif, kualitatif, dan R\&D. Bandung : Alfabeta

[19] Terry, George R, Leslie W, \& Rue. (2011). Principles of management. Jakarta: Bumi Aksara 